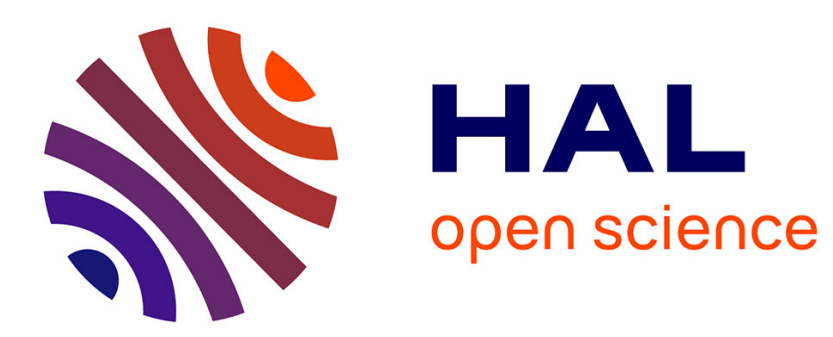

\title{
Gothique, réforme et Panoptique
}

Claire Wrobel

\section{To cite this version:}

Claire Wrobel. Gothique, réforme et Panoptique. Revue d'études benthamiennes, 2010. hal-02182597

\section{HAL Id: hal-02182597 \\ https: / hal.sorbonne-universite.fr/hal-02182597}

Submitted on 12 Jul 2019

HAL is a multi-disciplinary open access archive for the deposit and dissemination of scientific research documents, whether they are published or not. The documents may come from teaching and research institutions in France or abroad, or from public or private research centers.
L'archive ouverte pluridisciplinaire HAL, est destinée au dépôt et à la diffusion de documents scientifiques de niveau recherche, publiés ou non, émanant des établissements d'enseignement et de recherche français ou étrangers, des laboratoires publics ou privés. 


\section{Gothique, réforme et Panoptique ${ }^{1}$}

Claire Wrobel (Université Panthéon-Assas)

Revue d'Études Benthamiennes, $\mathrm{n}^{\circ} 7$ (2010)

<http://etudes-benthamiennes.revues.org/214>

\section{Introduction}

Jamais construit, jamais occupé, le Panoptique de Bentham demeure une architecture virtuelle qu'il est possible d'interpréter, de rêver ou de «cauchemarder » avec peut-être plus de liberté que si elle s'était incarnée dans la pierre. Si d'un côté, des recherches récentes ont permis de préciser l'évolution historique de ce projet dans la pensée de Bentham, dans d'autres domaines, le Panoptique est un paradigme utilisé pour lire la littérature anglosaxonne de la fin du XVIIIe siècle dans son contexte discursif. ${ }^{2}$ Cette seconde approche porte la marque de Surveiller et punir, ouvrage de Michel Foucault dans lequel celui-ci interprète le Panoptique comme l'archétype des disciplines modernes. Le spécialiste de Bentham peut s'en amuser ou s'en irriter : toujours est-il que les analyses de Foucault ont assuré une postérité herméneutique au Panoptique, notamment pour lire la littérature gothique.

Le gothique en littérature est une création de la critique du XXe siècle, un mouvement identifié rétrospectivement: au XVIIIe siècle, le courant que l'on qualifie à présent de « gothique » n'était ni conscient ni unitaire. ${ }^{3}$ Parmi les nombreuses approches qui existent, le genre peut être envisagé comme un phénomène historique, émergeant avec le Castle of Otranto (1764) de Horace Walpole et disparaissant dans les années 1820 après un pic de production dans les années $1800 .{ }^{4}$ Gothic était au XVIIIe siècle un terme idéologiquement surdéterminé, synonyme de barbare, médiéval et surnaturel..$^{5}$ Le caractère gothique de certains romans tient avant tout à leur cadre : des édifices médiévaux généralement déjà en ruines. Cependant, les romans gothiques sont surtout gothiques parce qu'ils reprennent les préjugés de l'époque concernant le Moyen Age, censé être caractérisé par le despotisme et la superstition. Les intrigues reposent souvent sur la confrontation d'un personnage anachronique, au sens où il incarne les valeurs du XVIIIe siècle éclairé, avec ces forces du passé.

Dans un entretien intitulé «L'œil du pouvoir », Foucault met en rapport Bentham et Ann Radcliffe (1764-1823), considérée comme l'une des fondatrices du genre, quand il affirme que les paysages des romans de celle-ci sont la «contre-figure » de la transparence que des projets comme le Panoptique ont tenté d'établir à la fin du XVIIIe siècle :

Les romans de la terreur, à l'époque de la Révolution, développent tout un fantastique de la muraille, de l'ombre, de la cache et du cachot, qui abritent, dans une complicité qui est

\footnotetext{
${ }^{1}$ Cet article est tiré de la communication présentée le 13 décembre 2008 au cours d'un des ateliers sur l'utilitarisme organisés par le centre Bentham. Cette communication avait permis d'exposer un travail de recherche doctoral, intitulé « Gothique et Panoptique : lecture croisée des œuvres d'Ann Radcliffe et de Jeremy Bentham » et dirigé par M. Cornelius Crowley, Professeur à l'Université de Paris Ouest-Nanterre-La Défense. Cette thèse a été soutenue en novembre 2009.

${ }^{2}$ Voir pour le premier aspect, Brunon-Ernst, «Les Métamorphoses du Panoptique », Cahiers critiques de philosophie ; pour le second : Townshend, The Orders of Gothic.

${ }^{3}$ Watt, Contesting the Gothic, p. 1, p. 6.

${ }^{4}$ Miles, «The 1790s: The Effulgence of Gothic », pp. 41-42.

${ }^{5}$ Longuel, «The word 'Gothic'», pp. 453-454. «Barbare » renvoie ici,d'un point de vue historique, aux tribus germaniques responsables de la destruction de Rome et associées, d'un point de vue esthétique, à une architecture désordonnée.
} 
significative, les brigands et les aristocrates, les moines et les traitres : les paysages d'Ann Radcliffe, ce sont des montagnes, des forêts, des cavernes, des châteaux en ruine, des couvents dont le silence et l'obscurité font peur. Or, ces espaces imaginaires sont comme la 'contrefigure' des transparences et des visibilités qu'on essaie d'établir. ${ }^{6}$

En dehors de ce rapprochement effectué par Foucault, existe-t-il des points de contact entre le philosophe et les auteurs gothiques? Comment penser, de façon plus générale, les rapports entre littérature gothique et l'entreprise de réforme, en particulier pénale et carcérale, dans l'Angleterre de la fin du XVIIIe siècle?

\section{1. cartographie et téléologie}

Bentham ne renvoie pas explicitement à la littérature gothique et il ne semble pas que le Panoptique ait inspiré directement de romans gothiques contemporains de son élaboration, dans les années 1790. Pour théoriser le rapport entre Panoptique et roman gothique du XVIIIe siècle, il faut revenir à la notion de «contre-figure » et au passage de «L'œil du pouvoir » précédemment cité. Foucault s'y intéresse à ce qu'il appelle des « espaces imaginaires ». Il évoque « un fantastique de la muraille, de l'ombre, de la cache et du cachot, qui abritent, dans une complicité qui est significative, les brigands et les aristocrates, les moines et les traîtres » ou encore, dans les romans de Radcliffe, «des montagnes, des forêts, des cavernes, des châteaux en ruine, des couvents dont le silence et l'obscurité font peur. » Foucault nous invite manifestement à nous intéresser à des questions d'espace.

Une première interprétation possible de ce passage consiste à dire que les romans gothiques sont dans un rapport de complicité avec l'entreprise d'instauration de la transparence qui domine la fin du XVIIIe siècle. On pourrait alors dire que les romans gothiques ont été écrits à une époque de transition, une époque où le règne de la transparence est en train d'être établi mais doit encore advenir. Les espaces sombres des romans gothiques figureraient les zones d'ombre à éradiquer à l'étranger. L'espace moderne est alors un espace transparent, éclairé d'une lumière constante et uniforme, un espace régulier, qui ne présente pas d'obstacle au regard et dans lequel le pouvoir s'exerce de manière homogène. Par contraste, l'espace gothique est par endroits opaque et présente des obstacles qui empêchent le regard de le quadriller. Le pouvoir s'y exerce de manière irrégulière, parfois excessive. Cette cartographie est indissociable d'une téléologie : la conception de l'espace va de pair avec une conception du temps ou de l'histoire, qui a les Lumières pour horizon.

A la fin du XVIIIe siècle, deux types de cartographie de l'abus politique coexistaient. Dans la littérature gothique, France, Espagne, Italie et parfois Portugal étaient interchangeables et fonctionnaient de façon similaire dans les représentations anglaises. L'espace gothique abritait des tyrans capricieux qui exerçaient un pouvoir absolu sur les biens, les personnes et les vies à l'opposé du rule of law censé régner en Angleterre après la Glorieuse Révolution. La torture y était pratiquée et le sort des sujet y était incertain. Préjugé politique et préjugé religieux allaient de pair : les romans gothiques se situent en grande majorité dans des pays catholiques, marqués par la superstition et l'hypocrisie. Le château féodal et le couvent sont des cadres privilégiés dans les romans gothiques, ce qui témoigne de l'association entre préjugé politique et religieux et d'une vision particulièrement négative du Moyen Age. La fonction idéologique du roman gothique était de présenter, par un jeu de contrastes, le XVIIIe siècle comme une époque libérée et éclairée. Le gothique servait de "miroir » aux mœurs et valeurs du XVIIIe siècle anglais. ${ }^{7}$ Le terme Gothic renvoyait en effet à un amalgame de coutumes religieuses, politiques, et morales rejetées comme non-anglaises, ce qui permettait de créer une identité nationale. L'idéologie qui sous-tend le roman gothique apparaît comme un discours auto-

\footnotetext{
${ }^{6}$ Foucault, «L'œil du pouvoir », p. 18.

${ }^{7}$ Botting, «In Gothic Darkly », p. 3.
} 
satisfait des Anglais, qui au XVIIIe siècle, s'estimaient libérés du despotisme par la Glorieuse Révolution, de la superstition catholique par la Réforme et de la cruauté par la sensibilité.

En revanche, les réformateurs identifiaient des aires «gothiques » dans le système carcéral anglais, à cette même époque censée être éclairée : les prisonniers étaient selon eux soumis au pouvoir despotique et arbitraire du geôlier, dans des espaces insalubres échappant à tout regard, notamment médical. Le traitement subi, par exemple la faim, était dénoncé comme une forme de torture, de même que l'incertitude dans laquelle se trouvaient de nombreux prisonniers quant à leur sort. Le projet de réforme consistait à identifier et éradiquer ces zones de non-droit. La même téléologie sous-tend la vision de l'histoire présente dans les romans gothiques et le discours réformateur, avec cette différence que pour les réformateurs, la libération n'était pas achevée mais constituait un horizon à atteindre. Il est cependant possible de proposer une deuxième articulation entre roman gothique et réforme pénale, dans laquelle le roman gothique représente, en les mettant à distance temporelle et géographique, les zones d'ombre persistant dans la société anglaise. A ce titre, le roman gothique est complice de l'entreprise de rationalisation du domaine pénal et de l'espace carcéral qui caractérise la fin du XVIIIe siècle.

Le philanthrope John Howard a effectué, dans les années 1770 et 1780, quatre tournées de visites dans les prisons anglaises pour faire paraitre The State of the Prisons en 1777 et proposer des éditions révisées. La prison ne devait pas pour lui être un lieu de promiscuité et de souffrance, mais un lieu de réforme morale et religieuse, ce qui passait notamment par la discipline. Son but était de mettre en évidence ce qui, dans le système carcéral anglais, empêchait d'atteindre ces objectifs et d'étudier à l'étranger les institutions à imiter et celles à éviter. Il fallait pour cela rendre l'espace carcéral visible, l'ouvrir à l'inspection. Bentham n'a pas proposé d'état des lieux systématique des prisons anglaises, mais s'est joint au chœur des dénonciations de la cruauté et de l'inefficacité du système carcéral.

Bentham décrit son temps comme une ère de libération et de progrès. Certaines méthodes punitives archaïques et cruelles tendent à disparaître: "These monastic institutions [flagellations, and other such ceremonies] have not been in fashion in our country for ages $\gg{ }^{8}$ Cependant, d'autres sont toujours pratiquées. Pour Bentham comme pour Howard le processus de modernisation est en marche mais n'a pas abouti : il faut le mener à son terme. Il dénonce l'usage persistant des fers : «that inexhaustible fund of disproportionate, too often needless, and always unpopular severity, not to say torture - the use of irons. » ${ }^{9}$ Il insiste sur la nécessité de faire disparaître les chaînes, ce qui constituerait un gain d'humanité. Comme le souligne Foucault, le Panoptique est un dispositif léger qui permet une économie de moyens, de violence et de souffrance: «Bentham s'émerveillait que les institutions panoptiques puissent être si légères : plus de grilles, plus de chaînes, plus de serrures pesantes ; il suffit que les séparations soient nettes et les ouvertures bien disposées. ${ }^{10}$

Lorsque Bentham veut dénoncer une pratique, il l'assimile à la torture. Il s'oppose aux pratiques punitives qui, quand elles affectent la santé des prisonniers, peuvent en devenir l'équivalent :

Styled less than capital, [punishments operating in abridgement of life] are in fact capital, and much more; the result of them being not simple and speedy death, as in the instances where death is appointed under that name, but death accompanied and preceded by lingering torture. ${ }^{11}$

\footnotetext{
${ }^{8}$ Bentham, Panopticon, Bowring IV, p. 65.

${ }^{9}$ Ibid., italiques dans le texte original.

${ }^{10}$ Foucault, Surveiller et punir, p. 236.

${ }^{11}$ Bentham, Panopticon, Postscript II, Bowring IV, p. 123.
} 
Selon lui, la faim, qu'elle soit utilisée comme punition ou soit le résultat de la négligence, est une forme de torture : " I should speak honestly, and call [hunger] torture-I should use it instead of a thumb-screw: it is applying the rack to the inside of a stomach, instead of the outside of a limb. ${ }^{12}$ Bentham fait preuve de préoccupations humanitaires et hygiénistes récurrentes chez les réformateurs. Il dénonce les conditions de détention (faim, froid, humidité, bruit) et en particulier les conditions sanitaires (odeurs, maladies, vermine). Dans Principles of Penal Law, il propose une liste des maux qui accompagnent en général l'emprisonnement, liste qui inclut la mauvaise alimentation, le mauvais couchage, le manque de lumière et la promiscuité forcée avec les autres prisonniers. ${ }^{13}$

Il insiste également sur le fait que les prisons ne remplissent pas leur fonction de réforme. Dans Rationale of Punishment, il pose douze principes afin d'identifier la peine la plus acceptable. Parmi ceux-ci, figure l'idée que la peine doit réformer le criminel et non l'encourager dans ses vices. ${ }^{14}$ Or Bentham, comme beaucoup, constate que les prisons échouent dans leur tâche de réforme morale : «Prisons [...] have commonly and very properly been styled schools of vice. ${ }^{15}$ Il estime que le problème de la promiscuité forcée entre les prisonniers ne peut être résolu que par l'architecture : « [I]t is [...] an evil which cannot be obviated without a change in the system and construction of prisons. $\rangle^{16}$

La réforme des prisons passe par la rationalisation de l'espace carcéral, afin de l'ouvrir au regard de l'inspection. Dans le Panoptique, l'obscurité doit disparaître. Bentham imagine un système de lampes et de réflecteurs afin de faire pénétrer la lumière dans tous les recoins des cellules, de jour comme de nuit: «to extend to the night the security of the day ${ }^{17}$ Le Panoptique prive la nuit de son obscurite : «In a dark night, it might be said, the benefit of the inspection principle fails you. Yes, if there be no lamps sufficient to light the walls;-yes, if there be no watchman patrolling in the house. ${ }^{18}$ La disparition de l'obscurité va de pair avec une maîtrise totale de l'espace :

Cells, communications, outlets, approaches, there ought not any where to be a single foot square, on which man or boy shall plant himself - no not for a moment - under any assurance of not being observed. Leave but a single spot thus unguarded, that spot will be sure to be a lurking-place for the most reprobate of the prisoners, and the scene of all sorts of forbidden practices. ${ }^{19}$

Comme l'espace, le temps doit être maîtrisé. Le Panoptique permet la victoire de l'espace sur le temps. L'inspection peut être effectuée d'un seul coup d'œil : «[N]o sooner is the superintendent announced, than the whole scene opens instantaneously to his view. ${ }^{20}$

Dans des lettres peu étudiées qui suivent les écrits sur le Panoptique dans l'édition de Bowring, Bentham établit un contraste entre le projet panoptique et le plan de déportation des prisonniers en Australie, qui s'appelait alors Nouvelle-Galles du Sud. ${ }^{21}$ Il propose un relevé topographique qui repose sur des catégories similaires à la cartographie des romans gothiques et de State of the Prisons. Bentham "gothicise » 1'espace australien en lui attribuant des qualités qui étaient associées au terme "gothique » à l'époque. La Nouvelle-Galles du Sud

\footnotetext{
12 Ibid., p. 154.

${ }^{13}$ Bentham, Principles of Penal Law, Bowring I, pp. 421-422.

${ }^{14}$ Ibid., p. 404. Voir Semple, Bentham's Prison, pp. 26-27.

${ }^{15}$ Bentham, Principles of Penal Law, p. 429 ; italiques dans le texte original.

${ }^{16}$ Ibid., p. 422.

${ }^{17}$ Bentham, Panopticon, p. 41.

${ }^{18}$ Bentham, Panopticon, Postscript I, pp. 108-109; c'est moi qui souligne.

${ }^{19}$ Bentham, Panopticon, p. 86.

${ }^{20}$ Ibid., p. 46.

${ }^{21}$ Cette analyse a été présentée de façon plus complète dans l'article « A Gothic Dystopia at the Antipodes ».
} 
était selon lui une terre d'arbitraire politique, soumise au caprice tyrannique du gouverneur, et où les droits des citoyens britanniques n'étaient pas respectés. De même que l'espace gothique, la Nouvelle-Galles du Sud est l'anti-rule of law. Bentham devait décrire, dans $A$ Plea for the Constitution, la Nouvelle-Galles du Sud comme une terre où la loi n'a pas cours : « New South Wales [has] nothing in it that ever was a law, or so much as called a law ». De plus, comme le parlement anglais n'avait pas pris la peine de préciser les modalités de l'exercice de la justice, le gouverneur, d'après Bentham, avait toute liberté d'instaurer des tribunaux dont il était le seul membre, pour juger des délits définis par lui-même. On retrouve alors la situation mise en scène dans The Italian, de Radcliffe, lorsque le héros, Vivaldi, est jugé par l'Inquisition et s'exclame : «How! [...] [I]s the tribunal at once the Prosecutor, Witness, and Judge! $\gg^{22}$ La Nouvelle-Galles du Sud constitue donc, en termes politiques, un double inverse de ce que l'Angleterre était censée être et représente dans ce texte l'équivalent de l'Espagne ou de l'Italie dans les romans gothiques.

L'espace de la Nouvelle-Galles du Sud a ceci de gothique qu'il contient de nombreuses zones qui échappent au regard de l'inspection. A l'époque où Bentham écrit ses lettres à Lord Pelham, le territoire ne pouvait être contrôlé par les grilles du pouvoir. De même que dans les prisons surpeuplées décrites par Howard, les détenus constituaient une masse indéfinie et pouvaient échapper au pouvoir individuant de la surveillance. De façon générale, l'espace australien était obscur, irrégulier et pouvait abriter des conspirations. Les déportés étaient dispersés à travers un territoire mal maîtrisé et Bentham devait écrire: "Under the transportation system [...] the state of the convict [...] was and is [...] thrown as it were purposely into the shade », ce qui s'oppose à la lumière ininterrompue du panoptique. ${ }^{23} \mathrm{La}$ réforme des prisonniers ne pouvait être effectuée et Bentham présente la Nouvelle-Galles du Sud comme une terre de vice, ce qui rappelle le discours des réformateurs sur les prisons, souvent appelées «séminaires » ou «écoles du vice». Bentham recommandait une maîtrise intensive de l'espace, impossible dans les vastes étendues de la Nouvelle-Galles du Sud.

De façon plus métaphorique, Bentham signale des zones d'ombre dans le droit pénal et dans le système politique anglais et utilise une rhétorique gothique à cet effet. «Rhétorique gothique » renvoie ici à un ensemble d'images et de scénarios présents à la fois dans la fiction gothique et le discours réformateur de la fin du XVIIIe siècle. Le gothique est alors considéré comme un terme historique, un terme idéologique et une source de métaphores.

\section{La rhétorique gothique de Bentham}

D'autres textes du corpus benthamien peuvent être convoqués pour y chercher la présence éventuelle d'une rhétorique gothique, notamment la critique du common law dans A Fragment on Government et A Comment on the Commentaries. L'attitude courante envers le common law, incarnée par Blackstone, était de le vénérer comme le réceptacle de la sagesse accumulée à travers les âges et, en cas de difficultés, de chercher à l'amender plutôt que de l'éradiquer. Bentham s'érige contre le fonctionnement mystérieux de ce type de loi : la vénération dont elle est l'objet la rend opaque, en empêche l'examen et donc la réforme. La «rhétorique gothique » de Bentham apparaît dans ce passage :

[I]t is not for every man in matters of moral science to define his words. It is what a little understanding can not do: a timid heart dare not do it. Men who, fettered by engagements, have abjured the right of thinking and find it their interest to persist in their abjuration, start from a task like this with loathing and with terror. They dare not venture into the recesses of the science for fear of spying out deformities which to correct would be mortal to their hopes: helpless victims of $a$ blind and antiquated policy, they dare not look their own notions in the face: they

\footnotetext{
${ }^{22}$ Radcliffe, The Italian, p. 206.

${ }^{23}$ Bentham, Letters to Lord Pelham, 185 ; italiques dans le texte original.
} 
dare not strike out those hidden | | where they would elicit hidden lights that would appal them with the prospect of the absurdities they have swallowed $[\ldots]^{24}$

Bentham affirme ici que le travail de définition requis pour améliorer le droit anglais est une entreprise qui peut être effrayante dans la mesure où elle va mettre en évidence les « difformités » et «absurdités » qui ont longtemps été acceptées. Le droit est présenté comme un espace irrégulier présentant des recoins (recesses) dans lesquels il faut porter la lumière. La tradition juridique est «aveugle », «vétuste» et «entrave» littéralement les sujets britanniques. Cette dénonciation du manque de définition dans le droit s'inscrit dans la critique du langage présente dans l'œuvre de Bentham. Ailleurs, il décrit à la fois le common law et le texte des Commentaries on the Laws of England de Blackstone comme des labyrinthes, éléments architecturaux récurrents dans les romans gothiques où les héroïnes se trouvent livrées au pouvoir arbitraire des villains. ${ }^{25}$

Bentham «gothicise » également l'université d'Oxford, où Blackstone a présenté les Commentaries. Après avoir déploré le manque d'exactitude et le recours à des ornements rhétoriques, il écrit :

The flaccid fopperies of Poetry and Rhetoric might flourish in the dank atmosphere his Commentaries first drew. Those who dare not judge, may venture to imagine. But the firm beauties of precision love a purer air. They grow not in those torpid and pestilential regions, where the grim spectre of superstition sits centinel over the foundations of moral science. Vain are his hopes who thinks to learn to see clearly in that gloomy circle, in which the first vow he makes at entering is to shut his eyes. ${ }^{26}$

Bentham utilise les adjectifs « dank » et «gloomy», souvent employés pour décrire les cachots souterrains et châteaux gothiques, afin de caractériser l'université anglaise. Celle-ci est également évoquée comme un domaine «torpide et pestilentiel», gouverné par la superstition. En reprenant ces éléments architecturaux, Bentham propose une variation sur le célèbre passage des Commentaries de Blackstone dans lequel ce dernier compare le droit anglais à un château gothique, que l'habitant moderne conserve et adapte à ses besoins. ${ }^{27}$ Pour Bentham, il ne fallait pas préserver le château gothique du droit anglais mais le raser pour mieux reconstruire.

Ce qui est structurellement gothique dans le common law, c'est que les décisions passées, les décisions des morts, pèsent sur les vivants, qui ne peuvent formuler de nouvelles lois selon le seul critère valable, à savoir l'utilité. Le poids des morts et de leurs actions passées sur les vivants est mis en scène de façon récurrente dans les romans gothiques. Dans la préface à The Castle of Otranto, Walpole reprend la citation biblique selon laquelle les péchés des pères sont expiés par leur descendants jusqu'à la troisième et quatrième générations. De nombreux romans gothiques reposent sur des usurpations et des assassinats dont les générations suivantes héritent sous la forme de spectres : c'est la trame de The Old English Baron, de Clara Reeve, par exemple. Bentham refuse ce qu'il appelle la «tyrannie des morts » dans le droit mais aussi en politique, ce qui apparaît en particulier dans ses écrits sur la Révolution française. Il s'oppose à l'inscription de principes immuables dans des documents constitutionnels, qu'il s'agisse de l'ancienne constitution anglaise ou de la Déclaration des

\footnotetext{
${ }^{24}$ Bentham, A Comment, Appendix F, Prefatory Materials, 320; c'est moi qui souligne. Burns et Hart signalent un mot manquant.

${ }^{25}$ Cf Bentham, A Comment, p. 17, pp. 114-115, p. 123, p. 221 et Of Laws in General, note p. 3.

${ }^{26}$ Bentham, A Comment, $12 \mathrm{n}$; italiques dans le texte original.

${ }^{27}$ Blackstone, Commentaries on the Laws of England, vol. 3, p. 268.
} 
droits de l'homme et de la constitution française. Bentham critique « la volonté récurrente de diriger la postérité, la bonne vieille recette qui permet aux morts d'enchaîner les vivants. ${ }^{28}$

Enfin, dans The Book of Fallacies, le gothique est, avec les références à l'antiquité et à l'Orient, l'une des armes que Bentham utilise pour dénoncer les arguments fallacieux des opposants à la réforme. Il oppose le recours à la raison et à l'expérience présente d'une part au recours au passé d'autre part, ce qu'il appelle le «culte voué aux os d'hommes morts ». Superstition et idolâtrie se trouvent de nouveau associées, lorsque Bentham dénonce les arguments que certains utilisent au nom de la prudence :

To this class may be referred [...] the hydrophobia of innovation, and argument of the ghostseer, whose nervous system is kept in a state of constant agitation by the phantom of Jacobinism dancing before his eyes $[\ldots]^{29}$

Les références au fantôme et au spectre permettent de renvoyer à l'irrationnel et à l'infantile. Elles permettent aussi de souligner l'absence de fondement de ces craintes. Bentham définit son temps comme une époque où diables, fantômes, vampires et sorcières sont dispersés par la presse, signe de la marche du progrès. Il critique ce qu'il appelle l'argument «croquemitaine » utilisés par les opposants à la réforme parlementaire :

The hobgoblin, the eventual appearance of which is denounced by this argument, is anarchy; which tremendous spectre has for its forerunner the monster innovation. The forms in which this monster may be denounced are as numerous and various as the sentences in which the word innovation can be placed.

'Here it comes!' exclaims the barbarous or unthinking servant in the hearing of the affrighted child, when, to rid herself of the burthen of attendance, such servant scruples not to employ an instrument of terror, the effects of which may continue during life. 'Here it comes!' is the cry; and the hobgoblin is rendered but the more terrific by the suppression of its name.

Of a similar nature, and productive of similar effects, is the political device here exposed to view. ${ }^{30}$

Ici, Bentham rejette les histoires de fantôme comme le propre des domestiques et comme un instrument d'infantilisation. Le roman gothique ne se limite pas à des «histoires de fantôme ». Dans cette littérature, la superstition est mise à distance : elle est toujours l'apanage des domestiques, même si elle constitue une tentation dangereuse pour les protagonistes. C'est par son substrat idéologique et sa façon d'interroger la hantise que le gothique offre une confrontation fructueuse avec le texte benthamien.

Il n'est pas surprenant qu'une rhétorique gothique soit opérante quant il s'agit de contester la légitimité du pouvoir en place et de dénoncer le recours à l'irrationalité par lequel il se maintient. En effet, la littérature gothique entraîne ses lecteurs derrière la scène. Dans The Ghost-Seer (1789), de Schiller, est décrite une scène d'illusionnisme qui culmine avec l'apparition de faux spectres. Les mécanismes et astuces utilisés sont ensuite minutieusement expliqués. De façon similaire, dans The Italian (1797), Radcliffe emmène ses lecteurs dans les coulisses du pouvoir, religieux dans ce cas-ci. Lorsqu'Ellena et Vivaldi s'échappent du couvent de San Stefano, ils empruntent des voies souterraines dont certaines servent de coulisses pour mettre en scène de faux miracles : « used for the purpose of conveying secretly

\footnotetext{
28 «What is the source of this premature anxiety to establish fundamental laws? It is the old conceit of being wiser than those who will have more experience:- the old appetite of ruling posterity, the old recipe for enabling the dead to chain down the living », «Observations on the Draughts of Declaration of Rights », Rights, Representation and Reform, p. 185; traduit par De Champs, Déontologie politique, p. 202.

${ }^{29}$ Bentham, Book of Fallacies, Bowring II, p. 480 ;c'est moi qui souligne.

${ }^{30}$ Ibid., p. 418 ; italiques dans le texte original.
} 
to the shrine, such articles as were judged necessary to excite the superstitious wonders of the devotees. $»^{31}$ Le pouvoir repose ici sur la manipulation de la superstition et s'entoure de mystère pour mieux assurer son emprise. William Godwin, dans Enquiry into Political Justice (1793), devait faire le même constat, s'opposant à une conception ésotérique du pouvoir qu'il glose en ces termes : «There is a mystery in the art of government, which uninitiated mortals must not presume to penetrate. ${ }^{32}$ Paine présente quant à lui la monarchie comme une forme d'imposture et propose, par un geste récurrent dans la littérature gothique, de lever le voile sur sa réalité :

[W] hat is called monarchy, always appears to me a silly, contemptible thing. I compare it to something kept behind a curtain, about which there is a great deal of bustle and fuss, and a wonderful air of seeming solemnity; but when, by any accident, the curtain happens to be open, and the company see what it is, they burst into laughter. ${ }^{33}$

La critique radicale, par son rationalisme, se rapproche de la technique du surnaturel expliqué pratiquée par Radcliffe : les événements apparemment surnaturels sont expliqués de façon rationnelle - bien que pas toujours satisfaisante. Bentham, qu'il s'attaque au système juridique ou au système politique, dénonce le voile de mystère dans lequel se drapent les puissants pour assurer leur emprise. Il souligne en particulier la façon dont le droit est instrumentalisé par les hommes de loi. Pour évoquer l'opacité dans laquelle les législateurs et les juges maintiennent le droit, il utilise l'image biblique qui devait fournir le titre d'un recueil de nouvelles de Sheridan Le Fanu (1872) :

The great and, to speak of it by what it ought to be, illustrious standard of right and wrong, say they [lawyers], is locked up from us: that on paying large fees we may have small scantlings of it or rather extracts, short [?] specimens produced to us, from them, to squint at as through a glass darkly. Accordingly we now see it, as through a glass darkly: we might, were it but your pleasure, see it face to face. ${ }^{34}$

La stratégie de dénonciation de l'instrumentalisation du droit apparaît dans les romans gothiques : par exemple, dans deux de ses œuvres (The Castles of Athlin and Dunbayne et The Mysteries of Udolpho), Radcliffe met en scène un villain s'arrogeant le pouvoir d'interpréter le droit comme bon lui semble afin d'usurper les terres d'une femme qu'il séquestre. ${ }^{35}$ Cependant, dans les deux romans, les propriétaires légitimes font échouer les tentatives des villains par leur maîtrise du droit foncier. Dans The Mysteries of Udolpho, Emily rétorque à Montoni :

I am not so ignorant, Signor, of the laws on this subject, as to be misled by the assertion of any person. The law, in the present instance, gives me the estates in question, and my own hand shall never betray my right. ${ }^{36}$

Dans l'économie du roman, le passage représente un tournant, à partir duquel Emily s'émancipe de l'emprise de Montoni. Or c'est précisément en proposant un droit clair et donc

\footnotetext{
${ }^{31}$ Radcliffe, The Italian, p. 138.

${ }^{32}$ Godwin, Enquiry into Political Justice, p. 125.

${ }^{33}$ Paine, Rights of Man, p. 182.

${ }^{34}$ Ibid., Appendice E, p. 327 ; c'est moi qui souligne. Le point d'interrogation a été ajouté par les éditeurs. La référence biblique est I Corinthiens $13: 12$.

${ }^{35}$ Radcliffe, The Castles of Athlin and Dunbayne, p. 54 et The Mysteries of Udolpho, pp. 380-381.

${ }^{36}$ Radcliffe, The Mysteries of Udolpho, pp. 380-381.
} 
connaissable que Bentham entendait émanciper ceux qui étaient dominés par les hommes de loi, les prêtres et les politiciens.

Jusqu'à présent, le roman gothique a été envisagé d'abord comme la figuration d'un passé dont le XVIIIe siècle anglais s'estimait libéré, puis comme la contrepartie, en fiction, de l'entreprise de rationalisation spatiale et sociale des réformateurs : les grottes, couvents et châteaux évoqués par Foucault sont l'équivalent des cachots anglais, mais aussi de l'irrationalité du common law ou de la doctrine des droits naturels, que Bentham cherche à combattre. C'est en ce sens que l'on peut entendre «contre-figure » dans la citation de Foucault: les romans gothiques seraient complices du projet rationaliste de Bentham. Cependant, dans Surveiller et punir, l'affixe «contre» renvoie à un rapport complexe d'opposition et de juxtaposition. Ce fonctionnement du préfixe «contre » ouvre la possibilité de lire autre chose dans « contre-figure » qu'un rapport de complicité. ${ }^{37}$ Le terme de «contrefigure » peut renvoyer à un double rapport, à la fois complice et critique.

Les Gothic villains des romans gothiques sont souvent interprétés comme les représentants d'une époque féodale despotique et cruelle. Cependant, par bien des aspects, ils semblent incarner le pouvoir panoptique tel que Foucault le décrit dans Surveiller et Punir, notamment parce qu'ils fomentent des complots contre les protagonistes, tentent de quadriller et de maîtriser l'espace et contrôlent le discours social qui définit l'individu. Peut-on lire l'association d'un pouvoir de type panoptique à ces villains comme une critique implicite du Panoptique?

\section{3. une dimension critique?}

Complots et conspirations abondent dans les romans gothiques. Protagonistes et personnages secondaires se sentent poursuivis et observés, parfois à raison, parfois à tort. Les conspirateurs se dissimulent, investissant l'espace d'une menace fantomatique, toujours possible mais pas toujours vérifiable. Par exemple, dans A Sicilian Romance, les jeunes gens qui souhaitent aider Julia, l'héroïne à qui le Marquis de Mazzini, son père, veut imposer un mariage, redoutent la surveillance du Marquis. La moindre lueur leur donne à penser qu'ils ont été observés : «[T]his circumstance [...] induced them to suspect that their visit to Julia had been observed. ${ }^{38}$ La voix passive dissimule dans cet exemple l'instance surveillante. Si Radcliffe mobilise des conspirations «classiques », structurées de façon hiérarchique avec une tête identifiable, des agents et des instruments, elle met également en scène des effets de pouvoir impersonnels. Une forme de surveillance est perçue par les personnages, sans qu'il soit nécessairement possible d'identifier qui l'exerce. Les premiers chapitre de The Italian en fournissent une bonne illustration. Une personne non identifiée essaye de dissuader Vivaldi de se rendre à la villa Altieri, où réside Ellena, par des avertissements : «Your steps are watvhed; beware how you revisit Altieri ! ${ }^{39}$ Cette voix se fait entendre à plusieurs reprises mais, malgré ses efforts, Vivaldi ne parvient pas à lui donner un visage. L'identité de cet «ange gardien» d'un genre particulier ne sera dévoilée qu'à la fin du roman. Cette surveillance anonyme peut être rapprochée de la surveillance panoptique. De plus, les villains aspirent à l'exercice d'un pouvoir omniscient et omniprésent mais se trouvent parfois eux aussi pris dans les mailles d'un réseau de surveillance invisible et néanmoins perceptible. Ainsi, dans The Mysteries of Udolpho, le réseau est celui des galeries secrètes qui creusent les murs du château. Lorsque, soupçonné de s'être rendu maître des lieux par des moyens criminels, Montoni tente de se justifier, il est interrompu par une voix spectrale. Il s'agit en fait d'une personne dissimulée dans une galerie secrète, dont Montoni ignore l'existence. Ce

\footnotetext{
${ }^{37}$ Pour une analyse détaillée voir Wrobel, « Les cryptes du projet benthamien », L'Atelier.

${ }^{38}$ Radcliffe, A Sicilian Romance, p. 63.

${ }^{39}$ Radcliffe, The Italian, p. 372.
} 
dernier affirme : «We are overheard. ${ }^{40}$ Bien que les environs soient fouillés, personne n'est trouvé et la voix n'est pas identifiée. ${ }^{41}$ La dissimulation et la surveillance ne sont pas le fait des villains uniquement mais se généralisent.

De plus, l'intériorisation de la surveillance est mise en scène. Par exemple, dans The Romance of the Forest, la conversation entre l'héroïne Adeline et le domestique Peter, qui cherche à la prévenir du complot qui la vise, est interrompue par des phrases comme « for Heaven's sake speak lower: if we should be overheard, we are all blown up » ou encore « I'm so afraid we shall be seen $\gg .{ }^{42}$ Ces personnages aux aguets, conscients d'une surveillance toujours possible, confrontés à un pouvoir omniscient, omniprésent et invisible, occupent une place comparable à celle des prisonniers du Panoptique. La surveillance est ici toujours menaçante. La visibilité ne constitue alors pas une protection mais bel et bien un «piège ». ${ }^{43}$

La rhétorique des Lumières, opposant de façon systématique lumière et obscurité, transparence et opacité, uniformité et irrégularité présente un aspect manichéen qui est bouleversé dans les romans gothiques, et ceux de Radcliffe en particulier. Dans les romans gothiques, les espaces obscurs ont un fonctionnement ambigu et semblent réversibles. Fred Botting a bien mis en évidence cette ambivalence :

Linked to, even enclosed within, the principal Gothic sites like the castle and the ruin, labyrinths, underground passages, and secret vaults have a plural significance: they are sites of imprisonment and the licentious enactment of evil or prohibited desires and figures of fear, confusion, alienation, or mystery; they also become refuges or means of escape from pursuit as well as locations of hidden secrets and sudden discoveries. ${ }^{44}$

Par exemple, dans le deuxième roman de Radcliffe, A Sicilian Romance, la lumière est ambiguë parce qu'elle révèle les poursuivants comme les victimes. Lorsque l'héroïne s'échappe du couvent de St Augustin, elle est à la fois aidée et trahie par la lune. Les espaces obscurs et accidentés, les obstacles peuvent être à la fois menace et protection.

Paradoxalement, il arrive que les personnages, déjà enfermés par leurs ennemis, s'enferment dans une autre pièce ou s'enfoncent volontairement dans les profondeurs d'une grotte ou d'un labyrinthe pour échapper à leurs poursuivants. Ainsi, dans A Sicilian Romance, c'est en s'enfonçant dans les souterrains que Julia se protège du Duc: «[P]ursuing the windings of the cavern, she flew into its inmost recesses $\gg .{ }^{45}$ Les montagnes qui ont occulté la séquestration de la Marquise de Mazzini peuvent aussi abriter la fuite :

[T] he cavern [Julia] had passed wound beneath the range of mountains on whose opposite side stood the castle of Mazzini. The hills thus rising formed a screen which must entirely conceal their emergence from the mouth of the cave, and their flight, from those in the castle. ${ }^{46}$

Cependant, les personnages se rendent vite compte qu'ils ne peuvent s'échapper, et il ne reste plus qu'à utiliser la prison comme cachette, ainsi que le propose la mère de Julia :

\footnotetext{
${ }^{40}$ Radcliffe, The Mysteries of Udolpho, p. 289.

${ }^{41}$ Le lecteur apprendra par la suite qu'il s'agissaitde Du Pont, fait prisonnier, mais qui avait réussi à s'échapper. Ibid., p. 458.

${ }^{42}$ Radcliffe, The Romance of the Forest, p. 137.

${ }^{43}$ Foucault, Surveiller et punir, p. 234.

${ }^{44}$ Botting, « Power in the darkness », p. 249.

${ }^{45}$ Radcliffe, A Sicilian Romance, p. 172.

${ }^{46}$ Ibid., p. 181.
} 
If $[\ldots]$ you prefer imprisonment with your mother, to a marriage with the duke, you may still secret yourself in the passage we have just quitted, and partake of the provision which is brought me $[\ldots]^{47}$

Il s'agit d'un double enfermement : pour échapper à une forme d'emprisonnement, les personnages choisissent de s'enfermer eux-mêmes. Ce double enfermement est paradoxal puisque les personnages choisissent la réclusion pour garder leur liberté. ${ }^{48} \mathrm{Il}$ serait facile de multiplier les exemples de ce double enfermement paradoxal, qui souligne le fonctionnement ambigu des espaces obscurs. Ceux-ci ne sont plus alors uniquement synonymes d'abus mais aussi de liberté.

Enfin, dans A Sicilian Romance, Radcliffe montre que la transparence peut être feinte pour duper l'opinion. Afin de dissiper les rumeurs affirmant que l'aile sud de son château est hantée, le Marquis de Mazzini emmène les domestiques explorer cette aile. Bien qu'il affirme présenter tout l'espace à leurs yeux, il ne leur montre que ce qu'il veut et surtout pas la grotte dans laquelle il séquestre sa première femme. L'obscurité, la profondeur, la présence d'obstacles ne contribuent pas forcémentà dissimuler les abus de personnages tyranniques. De même, la transparence n'est pas nécessairement une garantie de justice, de protection et de vérité : elle peut être simulée afin de duper d'autres personnages et ainsi devenir opacité. Radcliffe semble suggérer que même l'ouverture de l'espace gothique au public n'est pas une garantie.

Les romans gothiques ne présentent pas une critique directe du Panoptique. Cependant, le traitement ambigu des espaces obscurs, de la surveillance et de la transparence peut être lu comme une exploration ambivalente d'un univers hanté par la possibilité du «devenir Panoptique » du monde. Les romans gothiques se sont développés après une première vague de réforme carcérale. Ils ne prétendent pas faire un état des lieux des prisons à réformer en Angleterre. Les prisons de ces romans ne tiennent pas leur aspect terrifiant de la promiscuité ou la contagion qui pourraient y régner, mais de la suggestion d'un contrôle toujours possible. Les personnages traversent des espaces investis d'une surveillance impersonnelle, ce qui anticipe la possible généralisation du principe panoptique à l'ensemble de la société, c'est-àdire l'émergence de la société disciplinaire selon Foucault. Les romans gothiques constituent une mise en fiction du Panoptique tel qu'il a été interprété par un pan de la critique. Ils mettent en fiction la science sociale de Bentham pour mettre à l'épreuve un possible en cours.

\section{Conclusion}

Ce rapide parcours a permis d'identifier des points de contact entre littérature gothique et projet benthamien, au niveau thématique, rhétorique et idéologique. Faire entrer ces œuvres en dialogue nécessite d'adopter une perspective large : "gothique » ne renvoie pas qu'à un genre littéraire mais peut alors être entendu comme un terme historique, un terme idéologique et une source de métaphores. De plus, cette démarche engage à lire d'autres textes que ceux qui traitent uniquement du Panoptique : ceux qui concernent Blackstone et le common law ou encore la réforme parlementaire. L'hypothèse, dégagée rapidement ici et qu'il faudra vérifier

\footnotetext{
${ }^{47}$ Ibid., p. 183.

${ }^{48}$ Le paradoxe du double enfermement est également mis en évidence dans The Romance of the Forest et dans The Mysteries of Udolpho. Dans The Romance of the Forest, quand Adeline est enlevée par le Marquis de Montalt et séquestrée dans sa villa, elle ferme la porte de sa chambre à clé pour se protéger. (p. 163) Dans The Mysteries of Udolpho, quand Emily est poursuivie par un homme de Montoni, elle s'en protège en s'enfermant. (p. 385) Montoni promet Emily à plusieurs de ses hommes, si bien que la jeune fille est harcelée. Pour fuir cette situation, elle «s'échappe » en s'enfermant de nouveau: «Emily escaped the persecutions of Bertolini and Verezzi, by confining herself to her apartment ». Ibid., p. 442.
} 
de façon plus systématique, est celle de l'existence d'une rhétorique gothique dans l'ensemble des textes polémiques de Bentham.

L'étude des deux corpus montre qu'il est possible de proposer une interprétation dialectique de l'extrait de «L'œil du pouvoir » cité en introduction. Les romans gothiques entretiennent un rapport duel au discours autosatisfait des Lumières et au discours réformateur, founissant scénarios et armes rhétoriques aux deux. Le gothique s'inscrit dans un moment de transition, permettant de souligner les horreurs du système carcéral et interrogeant le désir de transparence qui anime le projet réformateur et le Panoptique en particulier. Les romans gothiques peuvent être interprétés comme une réaction à la possibilité panoptique, explorée dans sa version sombre par la fiction à défaut d'avoir été concrétisée.

Il n'existe pas de parallélisme clair entre les deux discours : le gothique fournit plutôt des perspectives dépravées sur le projet de science sociale. Il y aurait alors un gothique performatif qui déprogramme les textes programmatiques de Bentham. Un exemple tiré de la littérature gothique contemporaine semble le confirmer : dans Nights at the Circus, Angela Carter met en scène un pénitencier explicitement qualifié de "panoptique », destiné à réformer des criminelles, dont celles-ci parviennent à s'évader. Dans cet édifice, les consciences ne sont pas éveillées à la culpabilité, les esprits ne sont pas réformés, le système de contrôle des communications est contourné et - dernière ironie - la scène finale montre l'inspectrice enfermée dans la tour centrale alors que les prisonnières s'échappent dans l’immensité de la Sibérie.

\section{BIBLIOGRAPHIE}

\section{Sources primaires}

\section{Euvres gothiques}

CARTER, Angela, Nights at the Circus, Londres : Chatto and Windus, 1984.

RADCLIFFE, Ann, The Castles of Athlin and Dunbayne [1789] (A. Milbank, éd.), Oxford : Oxford UP, 1995.

—, A Sicilian Romance [1790] (A. Milbank, éd.), Oxford : Oxford UP, 1993.

—, The Romance of the Forest [1791] (C. Chard, éd.), Oxford : Oxford UP, 1986.

—, The Mysteries of Udolpho [1794] (B. Dobrée, éd.) Oxford : Oxford UP, 1998.

—, The Italian [1797] (E.J. Clery, éd.), Oxford : Oxford UP, 1998.

WALPOLE, Horace, The Castle of Otranto [1764], (W.S. Lewis, éd.), Oxford : Oxford UP, 1996.

\section{Euvres de Bentham}

The Works of Jeremy Bentham (J. Bowring, éd.), Edimbourg : William Tait, 1843.

Of Laws in General (H.L.A. Hart, éd.), Londres : Athlone Press, 1970.

A Comment on the Commentaries and A Fragment on Government (J.H. Burns et H.L.A. Hart, éds.), Londres : Athlone Press, 1977.

Rights, Representation, and Reform: Nonsense upon Stilts and other Writings on the French Revolution (P. Schofield, C. Pease-Warkins et C. Blamires, éds.), Oxford : Oxford UP, 2002.

\section{Autres}

BLACKSTONE, William, Commentaries on the Laws of England, [1765-1769], Chicago : Chicago UP, 2002.

GODWIN, William, Enquiry into Political Justice [1793], (K. Codell Carter, éd.) Oxford : 
Clarendon Press, 1971.

HOWARD, John, The Works of John Howard, 2 vols., vol. 1: The State of the Prisons in England and Wales, 4ème édition, Londres : J. Johnson, C. Dilly and T. Cadell, 1791-1792. PAINE, Thomas, Rights of Man [1790], Londres : Penguin, 1985.

\section{Sources secondaires}

\section{Sur le gothique}

BOTTING, Fred, « Power in the Darkness: Heteroropias, Literarure and Gothic Labyrinths », Genre, 1993, n 26, pp. 253-282 ; reproduit in F. Botting et D. Townshend (éds.), GothicCritical Concepts in Literary and Cultural Studies 4 vols, Londres : Routledge, 2004, I, pp. 243-268.

—, «In Gothic Darkly: Heterotopia, History, Culture » in D. Punter (éd.) A Companion to the Gothic, Oxford : Blackwell Publishers, 2000, pp. 3-14.

LONGUEL, Alfred E., « The word 'Gothic' in Eighteenth-Century Criticism », Modern Language Notes, $1923, \mathrm{n}^{\circ} 38$, pp. 459-460.

MILES, Robert, «The 1790s: the Effulgence of Gothic » in The Cambridge companion to Gothic Fiction, J.E. Hogle (éd.), 2002, pp. 41-60.

TOWNSHEND, Dale, The Orders of Gothic: Foucault, Lacan and the Subject of Gothic Writing, 1764-1820, New York : AMS Press, 2006.

WATT, James, Contesting the Gothic: Fiction, Genre and Cultural Conflict, 1764-1832, Cambridge : Cambrige UP, 1999.

\section{Sur Bentham et la réforme}

BRUNON-ERNST, Anne, Le Panoptique des pauvres, Paris : Presses de la Sorbonne nouvelle, 2007.

—, «Les Métamorphoses panoptiques : de Foucault à Bentham », Cahiers critiques de philosophie, été 2007, $\mathrm{n}^{\circ} 4$, pp. 61-71.

DE CHAMPS, Emmanuelle, La Déontologie politique ou la pensée constitutionnelle de Jeremy Bentham, Genève : Droz, 2008.

FOUCAULT, Michel, Surveiller et punir, Paris : Gallimard, 1975.

—, «L'œil du pouvoir », entretien avec J.-P. Barou et M. Perrot in Le Panoptique (J.-P. Barou, éd.), Paris : P. Belfond, 1977 (trad. M. Sissung).

SCHOFIELD, Philip, Utility and Democracy, Oxford : Oxford UP, 2006.

WROBEL, Claire, «A Gothic Dystopia at the Antipodes: New South Wales in Bentham's Letters to Lord Pelham », Gothic N.E.W.S. (Max Duperray, éd.), 2 vols., vol. 1, Paris : Michel Houdiard, 2009, pp. 111-124.

—, « Les cryptes du projet benthamien », L'Atelier, $\mathrm{n}^{\circ} 1$. $<$ http://latelier.u-paris 10.fr/index.php/latelier/article/view/7> 